\title{
Clinical case of delayed systemic sclerosis and pulmonary arterial hypertension diagnostics
}

\author{
L. I. Vasylieva, Ye. D. Yehudina, O. S. Kalashnykova* \\ State Institution “Dnipropetrovsk Medical Academy of the Ministry of Health of Ukraine”, Dnipro
}

Key words:

pulmonary

hypertension,

systemic

sclerosis, cardiac

catheterization.

Zaporozhye

medical journal

2019; 21 (2), 276-280

DOI:

10.14739/2310-1210.

2019.2.161515

*E-mail:

oksana.dma@gmail.com

Ключові слова:

мегенева

гіпертензія,

системна

скмеродермія,

катетеризація

серця.

\section{Запорізький}

медичний

журнал. - 2019. -

T. 21, № 2(113). -

C. 276-280

Ключевые слова:

мегочная

гипертензия,

системная

склеродермия,

катетеризация

серлца.

Запорожский

медицинский

журнал. - 2019. -

T. 21, № 2(113). -

C. 276-280

Pulmonary hypertension is a frequent and severe complication of systemic sclerosis (SSc). SSc-PAH patients have a worse prognosis than patients with idiopathic $\mathrm{PAH}$.

We report a case of a patient with delayed SSc and PAH diagnostics. Limited SSc was established in a 61-year-woman with 20 years of Raynaud's syndrome anamnesis. But diagnosis of SSc-PAH was determined in severe and late symptomatic stage with signs of right heart congestion, NYHA III FC and mPAP $48 \mathrm{mmHg}$. This emphasizes the need for clinicians to be aware of limited SSc and have a high index of $\mathrm{PH}$ suspicion in such patients.

\section{Клінічний випадок пізньої діагностики системної склеродермії та легеневої артеріальної гіпертензії}

\section{А. І. Васимьєва, Є. А. Єгудіна, О. С. Калашникова}

Легенева гіпертензія є частим та загрозливим ускладненням системної склеродермії. Прогноз у пацієнтів із легеневою артеріальною гіпертензією, що асоційована зі склеродермією, гірший порівняно з пацієнтами з ідіопатичною артеріальною гіпертензією.

Наведений клінічний випадок пізньої діагностики системної склеродермії та асоційованої з нею легеневої артеріальної гіпертензії. У пацієнтки віком 61 рік з 20-річним анамнезом синдрома Рейно вперше діагностована лімітована форма системної склеродермії на стадії виражених проявів легеневої гіпертензії із середнім тиском у легеневій артерії 48 мм рт. ст., тяжкої правошлуночкової серцевої недостатності та III ФК NYHА. Це показує необхідність обізнаності та своєчасної діагностики лімітованої форми склеродермії та потребує посиленої уваги в ранньому виявленні легеневої гіпертензії в таких хворих.

\section{Клинический случай поздней диагностики системной склеродермии и мегочной артериальной гипертензии}

\section{А. И. Васильева, Е. А. Егудина, О. С. Калашникова}

Легочная гипертензия является частым и серьезным осложнением системной склеродермии. Прогноз у пациентов с легочной артериальной гипертензией, ассоциированной со склеродермией, хуже в сравнении с пациентами с идиопатической легочной артериальной гипертензией.

Представили клинический случай поздней диагностики системной склеродермии и ассоциированной с ней легочной артериальной гипертензии. У пациентки в возрасте 61 год с 20-летним анамнезом синдрома Рейно была впервые диагностирована лимитированная форма системной склеродермии на стадии выраженных проявлений легочной гипертензии со средним давлением в легочной артерии 48 мм рт. ст., тяжелой правожелудочковой сердечной недостаточностью и III ФК NYHA. Это подчеркивает необходимость осведомленности и своевременной диагностики лимитированной формы склеродермии и требует повышенного внимания в раннем выявлении легочной гипертензии у таких пациентов.

Systemic sclerosis (SSc) is a multiorgan autoimmune connective tissue disease characterized by vasculopathy and fibrosis. The prevalence of SSc ranges from 7 million to 489 million [1].

Cardiorespiratory complications, such as pulmonary hypertension $(\mathrm{PH})$ and intersticial lung disease are the main causes of mortality in SSc patients [2]. Different types of PH may occur in SSc patients: pulmonary arterial hypertension associated with SSc (SSc-PAH), pulmonary veno-occlusive disease (PVOD), pulmonary hypertension associated with intersticial lung disease (PH-ILD), pulmonary hypertension associated with left heart disease (PH-LHD). Among them SSc-PAH is the most common studied variant with prevalence of $8-15 \%[3,4]$ and significantly lower survival rate in comparison with idiopathic PAH $[5,6]$. Without treatment the average life expectancy after symptoms manifestation has been 2-3 years [7]. Patients with teleangiectasia, anti-centromere antibodies, older age and longer disease duration are at the higher risk for developing PAH [8-10]. In Ukraine there is lack of epidemiological studies on PAH in SSc. According to the registry of SSc patients established in the Rheumatology Department of Mechnikov Dnipropetrovsk Regional Clinic the pulmonary artery pressure assessed by transthoracal echocardiography (TTE) was $23 \mathrm{mmHg}$ in 190 patients with SSc, among them $25.3 \%$ had pulmonary fibrosis [11].

Significant efforts have been made to improve the diagnostics and classification of PH. According to ESC/ERS guidelines $2015 \mathrm{PH}$ is defined as mPAP of $25 \mathrm{mmHg}$ or greater obtained by cardiac catheterisation at rest [12]. In March 2018, on the 6 World Symposium of PAH in NICE a new $\mathrm{PH}$ haemodynamic definition was proposed. Thus, mPAP > 20 mmHG should be considered as upper normal value and pre-capillary $\mathrm{PH}$ could be defined as mPAP 
$>20 \mathrm{mmHg}$, pulmonary artery wedge pressure (PAWP) $<15 \mathrm{mmHg}$ and pulmonary vascular resistance (PVR) $>3 \mathrm{WU}$. This definition allows to identify pulmonary vascular disease at an earlier stage. The impact of the new definition on the number of pre-capillary $\mathrm{PH}$ patients identified would be low with preliminary data suggesting an increase of less than $10 \%$ [13]. In the study of Coghlan et al., 71 patients with SSc were clinically assessed at baseline and after 3 years, including right heart catheterisation (RHC). Among them $3 \%$ developed $\mathrm{PH}$ and $7 \%$ developed SSc-PAH. PVR, tricuspid regurgitation velocity, diffusion capacity and the size of the inferior vena cava at baseline were independent predictors for the development of $\mathrm{PH}$ during follow-up [14].

Another study of J. V. Cristopher et al. demonstrates, that 16 SSc patients with borderline mPAP from 21 to $24 \mathrm{mmHg}$ have developed manifest PAH at the time of follow-up RHC (median follow up 45 months). At baseline catheterization these 16 patients with borderline $\mathrm{PH}$ had mPVR of $2.9 \mathrm{WU}$ and it increased to $4.9 \mathrm{WU}$ at follow up. Patients with borderline mPAP were more likely to develop $\mathrm{PH}$ than patients with $\mathrm{mPAP} \leq 20 \mathrm{~mm} \mathrm{Hg}$ [15].

$\mathrm{SSc}-\mathrm{PAH}$ belongs to Group 1 disease of the PH classification, at the same time the number of SSc patients with $\mathrm{mPAP}>20 \mathrm{mmHg}$ and PAWP $>15 \mathrm{mmHg}$ at rest is in the range of $20-45 \%[16,17]$. After significant parenchymal lung disease exclusion, they will be classified as $\mathrm{PH}$ due to SSc-PH-LHD, or Group 2 of the PH classification [12]. The underlying causes of LHD can include the presence or absence of valvular heart disease, heart failure with reduced ejection fraction or heart failure with preserved ejection fraction. Elevation in pulmonary vascular pressures can be related to several mechanisms: passive transmission of pressures from the left atrium, changes in vascular compliance due to elevated left atrial pressure [18] and changes in the pulmonary vascular tone or vascular remodeling.

Another challenge to the $\mathrm{PH}$ specialist may be diagnostics and treatment of PVOD in suspected SSc-PH patients. This condition remains poorly understood and accounts for $5-10 \%$ of cases initially misdiagnosed as IPAH. Haemodynamic presentation of PVOD is similar to IPAH, particularly with respect to wedge pressure, which is invariably normal in both disease conditions $[19,20]$, that was reflected in the ESC/ERS guideline PH 2009 [12]. In updated clinical classification (Nice 2018) PVOD was determined as PAH with overt sings of venous / capillaries (PVOD/PCH) involvement [13]. Recent genetic studies have shown that PVOD occurs sporadically or is inherited in families due to recessive mutations of the eukaryotic translation initiation factor 2 alpha kinase 4 (EIF2AK4) gene which encodes the GCN2 protein [21]. Clinicians should be aware in cases, when patient experiences worsening after initiation of the specific PAH treatment or becomes refractory to this therapy.

Major finding that has important implications for both the initial clinical classification of SSc-PH patients and their long-term management is change in hemodynamic classification over time. In the PHAROS cohort [22], $30 \%$ of patients changed their PAWP on follow-up RHC to the degree where they cross over the PAWP classification threshold of $15 \mathrm{mmHg}$, including almost one-quarter of patients who had an initial PAWP $\leq 15 \mathrm{mmHg}$. This occurred independently of whether the patient was placed on a $\mathrm{PH}$ medication. In the REVEAL registry, $16 \%$ of PAH patients with mixed etiology changed their PAWP enough on follow-up to have what is termed a "PAWP class change", at the same time $65 \%$ of patients with a PAWP $>15 \mathrm{mmHg}$ had a PAWP $<15 \mathrm{mmHg}$ on repeat $\mathrm{RHC}$ [23]. There are several explanations why PAWP may truly change in SSc-PH patients. First, patients who develop an elevated PAWP over time may simply have developed heart failure with preserved ejection fraction in addition to their underlying $\mathrm{PH}$, since heart failure is a disease associated with aging and diastolic dysfunction which is common in SSc [24]. But in the PHAROS study no increased baseline diastolic dysfunction was found in patients with an initial PAWP $<15 \mathrm{mmHg}$ who had an elevated PAWP on their follow-up RHC, there were no differences in TTE measurements of diastolic dysfunction or left atrial size when performed at the time of the second RHC, making progressive development of heart failure with preserved ejection fraction less likely [23]. Second, either improvements or decrements over time in right ventricular (RV) function can alter left heart filling pressures by RV-LV interdependence [25]. And the last one, therapies such as diuretics and $\mathrm{PH}$ medications may have altered PAWP.

SSc being a well-known risk factor for developing PAH, but there are still delays in diagnosing $\mathrm{PAH}$ and consequently more than $80 \%$ of patients present with the World Health Organization (WHO) functional class III or IV at this point [26]. Coghlan et al. reported the first evidence-based algorithm (DETECT) for the screening of PAH in SSc [9]. The DETECT algorithm is a tool to identify patients with $\mathrm{PAH}$ in the asymptomatic stages, through the study of clinical variables, pulmonary function tests, immunological, biological, electrocardiographic and finally, echocardiographic parameters. The application of the DETECT algorithm was conducted in two steps through the website PAH risk calculator (http://detect-pah.com) [27], the first step for referring the patient for echocardiography and the second for carrying out RHC [26]. The ESC/ESR 2015 PH guidelines introduce the DETECT algorithm as a valid method to be performed for annual screening of PAH in patients with SSc [12].

It is a very common situation for SSc patients, when several mechanisms can work together and lead to $\mathrm{PH}$. Careful phenotyping of PH in SSc is very important because it has an impact on treatment choice, therefore different treatments and strategies are indicated for the different subgroups of patients.

Despite the attention that $\mathrm{PH}$ has drawn in recent years, significant gaps remain in the management of challenging cases of PH in Ukraine.

In September 2016 a 63-year-old female presented to the centre with mixed dyspnea on a moderate exertion progressively increased over the last year; fatigue; episodes of burning or tightness in the chest and pain lasting more than a few minutes, getting worse with activity; chronic ankle edema; two pillow orthopnea for 2 months; pain in fingers and toes, their paleness, sensations of cold and numbness; back pain; dizziness while walking.

In 2015, the patient was hospitalized due to angioparalitic stage of Raynaud's syndrome to the Rheumatology Department of the City Hospital. She had peripheric artery disease with involvement of forearm and tibial arteries 
without hemodynamic abnormality. She noted a history of Raynaud's syndrome and sclerodactyly for more than 20 years, but she was not examined for scleroderma. Her medical history also included anamnesis of arterial hypertension for 35 years and ischemic stroke (March 2015). The patient was in menopause for 10 years, had one pregnancy with 1 normal birth in anamnesis.

Physical examination of the patient identified sclerodactyly, cyanosis, jugular vein pulsation. Thyroid gland was normal without masses. There was no adenopathy. Chest was hyposthenic and symmetric, nontender without masses or discharges. BMI was 26.7. RR was 22 per minute. Lung fields were clear to auscultation. BP was 145/95 $\mathrm{mmHg}$ sitting, HR was 92 per minute. Cardiac auscultation revealed systolic murmur on the left parasternal border and enhanced P2. Abdomen was symmetrical, soft, flat, bowel sounds were present, no bruits, nontender to palpation. Flunk dullness was noted on percussion. Liver edge was $+2 \mathrm{~cm}$, spleen, kidney did not palpate. Extremities examination revealed sclerodactyly, signs of chronic venous stasis changes in both legs, 1+ edema until the knees.

Bendopnea test [28,29]: BP was 130/85 mmHg and BR was 4 within 15 seconds in sitting position. While bending 30 seconds dyspnea occurred on the 10 second. After the patient returned in sitting position BP was $138 / 92 \mathrm{mmHg}$, BR was 7 within 15 seconds.

The 6-MWT distance was 192 meters with desaturation from $95 \%$ to $91 \%$ and pulse increased from 96 to 118 beats per minute. Borg dyspnea score was assessed as 4 .

Chest radiography revealed increased cardiothoracic ratio, clear lung fields with prominent central pulmonary arteries.

On ECG, there was left axis deviation, rhythm was sinus with HR 87 per minute and amplitude signs of right atrium enlargement.

The result of spirometry (FEV1 84 \%, FEV1/ FVC 126) did not reveal any abnormalities.

Clinical blood analysis: HGB $158 \mathrm{~g} / \mathrm{L}, \mathrm{RBC} 4.810^{12} / \mathrm{L}$, WBC $7.110^{9} / \mathrm{L}$; Platelets $202 \mathrm{~g} / \mathrm{L}$.

Biochemical analysis: total bilirubin 8 umol/L, LDL $3.1 \mathrm{mmol} / \mathrm{L}$, alkaline phosphatase $114 \mathrm{U} / \mathrm{L}, \mathrm{ALT} 18 \mathrm{U} / \mathrm{L} /$, AST $30 \mathrm{U} / \mathrm{L}$, creatinine $107 \mathrm{umol} / \mathrm{L}$, urea $350 \mu \mathrm{mol} / \mathrm{L}$, total protein $65 \mathrm{~g} / \mathrm{L}$, albumin $39 \mathrm{~g} / \mathrm{L}$, sodium $140 \mathrm{mmol} / \mathrm{L}$, potassium $5.0 \mathrm{mmol} / \mathrm{L}$. Differential diagnoses of HIV, hepatitis B and $C$ virus, thrombophilia, thyroid disorders were excluded by laboratory tests. NT-proBNP was $845 \mathrm{pg} / \mathrm{ml}$ (RR $<130 \mathrm{pg} / \mathrm{ml})$. Index-anticentromer antibody $\lg G>8$.

Based on ACR (including the LeRoy and Medsger modifications) and the EULAR Criteria for Systemic Sclerosis [30], limited SSc was diagnosed as the presence of Raynaud's syndrome plus SSc-specific autoantibodies.

Screening for PH using step 1 of the DETECT algorhithm showed 329 risk score.

Further testing included TTE which showed a markedly dilated RV (end-diastolic diameter $51 \mathrm{~mm}$ ) and right atrium (right atrium area $\left.31 \mathrm{~cm}^{2}\right)$, reduced tricuspid annular plane systolic excursion (TAPSE) $(10 \mathrm{~mm})$, severe tricuspid regurgitation (>2.6 mm/sec), RV/LV was 1.0 , at the same time estimated systolic pulmonary artery pressure (sPAP) was $107 \mathrm{mmHg}$, abnormal function of the interventricular septum (IVS), a nonhaemodynamic relevant pericardial effusion (100 $\mathrm{ml})$, and a dilated vena cava inferior $(9.7 \mathrm{~mm})$ were revealed. Left ventricle (LV) ejection fraction was $74 \%$, iLV mass $-64 \mathrm{~g} / \mathrm{cm}^{2}$. There were no signs of congenital heart disease.

After calculating the total risk score by step 2 of the DETECT algorithm, RHC was performed.

Hemodynamic evaluation by $\mathrm{RHC}$ verified pre-capillary PH: mPAP $48 \mathrm{mmHg}$, PAWP $9 \mathrm{mmHg}$ and PVR of 800 dyn ${ }^{*} \mathrm{sec} / \mathrm{cm}^{5}$, cardiac index $2.0 \mathrm{l} / \mathrm{min} / \mathrm{m}^{2}$. Mixed venous partial pressure of oxygen was $31 \mathrm{mmHg}$, arterial partial pressure of oxygen was $51 \mathrm{mmHg}$. Ventavis inhalation performed during $\mathrm{RHC}$ did not meet the criteria for an acute vasoreactive response.

Coronaroangiography findings included $65 \%$ stenosis of left anterior descending artery and $30 \%$ stenosis of left circumflex artery.

Abdomen ultrasound showed echo-signs of fatty liver disease. Portal vein was $1.0 \mathrm{~cm}$. The wall of gallbladder was thickened up to $0.4 \mathrm{~cm}$ and hyperechoic, echogenicity of pancreas was increased without masses. Marked aortic sclerosis was seen.

As a result, the patient's diagnosis was confirmed as mild PAH WHO FC II, associated with limited SSc, intermediate risk. III stage of right heart failure with RV systolic dysfunction and LV preserved systolic function.

PAH treatment was initiated with Revatio $60 \mathrm{mg}$ daily. Concomitant therapy consisted of Valsartan / Hydrochlorothiazide 160/12.5 mg daily, Acetylsalicylic acid $75 \mathrm{mg}$ daily, Atorvastatin $20 \mathrm{mg}$ daily, Thorasemide $10 \mathrm{mg}$ daily, Furosemide $40 \mathrm{mg}$ daily, Spironolactone $50 \mathrm{mg}$ daily. The patient had rheumatologist consultation, but no medications for SSc were administered.

The patient had remained clinically stable for 4 months. In March 2017, she was admitted to the hospital with tachycardia, worsening of right heart failure, signs of fluid retention and increased dyspnea, deterioration to NYHA III. There was atrial fibrillation on ECG with HR of 110 beats per minute and BP of $134 / 85 \mathrm{mmHg}$. Anticoagulation with Rivaroxaban $20 \mathrm{mg}$ daily was initiated immediately. Due to aggravation of heart failure symptoms, early cardioversion was considered.

On transesophageal examination, right ventricle outflow tract thrombus and left atrial appendage thrombus were found. These results pointed on management the patient with rate control therapy. After escalation of diuretic therapy and achievement of rate control between $90-100$ beats per minute, some improvement of right heart failure congestion symptoms was observed, but the patient still remained in NYHA III. In 6-MWT the covered distance was $170 \mathrm{~m}$. TTE hemodynamic parameters did not differ from baseline: RV/ LV 1.0; sPAP $105 \mathrm{mmHg}$, iS RA $19.4 \mathrm{~cm} / \mathrm{m}^{2}$, LVEF $65 \%$, paradoxical motion became more pronounced.

After clinical examination, we observed progression to NYHA FC III in our patient, but there were no TTE changes and no 6-MWD test decrease to $15 \%$. Right heart catheterization was not done due to presence of RVOT thrombus. Decision about sequential drug combination therapy was done and Ventavis was administered additionally.

The patient had remained in the same clinical status without improvement following initiation of combination therapy. In October 2017, she suddenly died.

Our clinical case demonstrates outcomes of delayed SSc and PH diagnostics. Thus, limited SSc was established 
in the 61-year-woman after 20 years of Raynaud's syndrome anamnesis. During hospitalization with paralytic form of Raynaud's syndrome in 2015 , our patient had already complained of dyspnea, but none of these symptoms were taken in a point for SSc suspicion and subsequent screening for PH with the DETECT algorithm. Diagnosis of PAH was determined in severe and late symptomatic stage with signs of right heart congestion, NYHA III FC and mPAP $48 \mathrm{mmHg}$. This emphasizes the need for clinicians to be aware of limited SSc and have a high index of $\mathrm{PH}$ suspicion in such patients. Ongoing follow-up and critical re-evaluation of the diagnosis with individual assessment of clinical status, co-morbidities and treatment efficacy are essential due to the high risk of cardiovascular complications.

Conflicts of interest: authors have no conflict of interest to declare. Конфлікт інтересів: віАсутній.

Надійшла Ао редакції / Received: 04.06.2018

Після Аоопрацювання / Revised: 06.02.2019

Прийнято АО Аруку / Accepted: 26.02.2019

Information about authors:

Vasylieva L. I., MD, PhD, Associate Professor of the Department of Internal Medicine 3, SI “Dnepropetrovsk Medical Academy of Health Ministry of Ukraine", Dnipro.

Yehudina Ye. D., MD, PhD, Associate Professor of the Department of Internal Medicine 3, SI "Dnepropetrovsk Medical Academy of Health Ministry of Ukraine", Dnipro.

Kalashnykova O. S., MD, PhD, Professor Assistant of the Department of Internal Medicine 3, SI “Dnepropetrovsk Medical Academy of Health Ministry of Ukraine", Dnipro.

\section{Відомості про авторів:}

Васильєва ^. І., канА. меА. наук, доцент каф. внутрішньо медицини 3, А3 "Аніпропетровська медична академія М0З України", м. Аніпро.

Єгудіна Є. А., канА. меА. наук, Аоцент каф. внутрішньої медицини 3, А3 "Аніпропетровська медична академія М03 України", м. Аніпро.

Калашникова О. С., канА. меА. наук, асистент каф. внутрішньої медицини 3, А3 “Аніпропетровська медична академія М03 України", м. Аніпро.

\section{Сведения об авторах:}

Васильева А. И., канА. меА. наук, Аоцент каф. внутренней медицины 3, ГУ "Анепропетровская медицинская академия МЗ Украины", г. Анипро.

Егудина Е. А., канА. меА. наук, Аоцент каф. внутренней медицины 3, ГУ "Анепропетровская медицинская академия МЗ Украины", г. Анипро.

Калашникова О. С., канА. меА. наук, ассистент каф. внутренней медицины 3, гу "Анепропетровская медицинская академия МЗ Украины", г. Анипро.

\section{References}

[1] Chifflot, H., Fautrel, B., Sordet, C., Chatelus, E., \& Sibilia, J. (2008) Incidence and Prevalence of Systemic Sclerosis: A systematic literature review. Semin Arthritis Rheum., 37(4), 223-35. doi: 10.1016/j. semarthrit.2007.05.003

[2] Abu-Shakra, M., \& Lee, P. (1995) Mortality in systemic sclerosis: a comparison with the general population. J. Rheumatol., 22(11), 2100-2102.

[3] Hao, Y., Thakkar, V., Stevens, W., Morrisroe, K., Prior, D., Rabusa, C., et al. (2015) A comparison of the predictive accuracy of three screening models for pulmonary arterial hypertension in systemic sclerosis. Arthritis. Res. Ther, 17,7 doi: 10.1186/s13075-015-0517-5
[4] Muangchan, C. Baron, M. \& Pope, J. (2013) The 15\% rule in scleroderma: the frequency of severe organ complications in systemic sclerosis: A systematic review. J. Rheumatol., 40(9), 1545-56. doi: 10.3899/ jrheum. 121380

[5] Fisher, M. R., Mathai, S. C., Champion, H. C., Girgis, R. E., Housten-Harris, T., Hummers, L., et al. (2006) Clinical differences between idiopathic and scleroderma-related pulmonary hypertension. Arthritis. Rheum., 54(9), 3043-3050. doi: 10.1002/art.22069

[6] Kawut, S. M., Taichman, D. B., Archer-Chicko, C. L., Palevsky, H. I., Kimmel, S. E., et al. (2003) Hemodynamics and survival in patients with pulmonary arterial hypertension related to systemic sclerosis. Chest, 123(2), 344-350. doi: 10.1378/chest.123.2.344

[7] D'Alonzo, G. E., Barst, R. J., Ayres, S. M., Bergofsky, E. H., Brundage, B. H., Detre, K. M., et al. (1991) Survival in patients with primary pulmonary hypertension. Results from a national prospective registry. Ann Intern Med., 115(5), 343-9.

[8] Steen, V. D., Lucas, M., Fertig, N., \& Medsger, Jr T. A. (2007) Pulmonary arterial hypertension and severe pulmonary fibrosis in systemic sclerosis patients with a nucleolar antibody. J. Rheumatol., 34, 2230-5.

[9] Coghlan, J. G., Denton, C. P., Grüniq, E., Bonderman, D., Distler, O., Khanna, D., et al. (2014) Evidence-based detection of pulmonary arterial hypertension in systemic sclerosis: the DETECT study. Ann. Rheum. Dis., 73(7), 1340-9. doi: 10.1136/annrheumdis-2013-203301

[10] Chung, L., Domsic, R. T., Lingala, B., Alkassab, F., Bolster, M., Csuka, M. E., et al. (2014) Survival and predictors of mortality in systemic sclerosis-associated pulmonary arterial hypertension: outcomes from the pulmonary hypertension assessment and recognition of outcomes in scleroderma registry. Arthritis Care Res., 66(3), 489-95. doi: 10.1002/ acr.22121

[11] Semenov, V., Kuryata, O., \& Lysunets, T. (2018) Clinical pattern of systemic sclerosis in Central Ukraine. Association between clinical manifestations of systemic sclerosis and hypertension. Reumatologia, 56(1), 24-30. doi: 10.5114/reum. 2018.74745

[12] Galiè, N., Humbert, M., Vachiery, J. L., Gibbs, S., Lang, I., Torbicki, A., et al. (2015) 2015 ESC/ERS Guidelines for the diagnosis and treatment of pulmonary hypertension: The Joint Task Force for the Diagnosis and Treatment of Pulmonary Hypertension of the European Society of Cardiology (ESC) and the European Respiratory Society (ERS): Endorsed by: Association for European Paediatric and Congenital Cardiology (AEPC) International Society for Heart and Lung Transplantation (ISHLT). Eur. Respir. J., 46(4), 903-75. doi: 10.1183/13993003.01032-2015

[13] Simonneau, G. (2018) PH haemodynamic definitions and clinical classifications and characteristics of specific PAH subgroups. Materials of 6 World Symposium on Pulmonary Hypertension. Nice.

[14] Coghlan, J. G., Wolf, M., Distler, O., Denton, C. P., Doelberg, M., Harutyunova, S., et al. (2018) Incidence of pulmonary hypertension and determining factors in patients with systemic sclerosis. Eur. Respir. J., 51(4), pii: 1701197. doi: 10.1183/13993003.01197-2017

[15] Valerio, C. J., Schreiber, B. E., Handler, C. E., Denton, C. P., \& Coghlan, J. G. (2013) Borderline Mean Pulmonary Artery Pressure in Patients With Systemic Sclerosis: Transpulmonary Gradient Predicts Risk of Developing Pulmonary Hypertension. Arthritis and Rheumatology, 65(4), 1074-84. doi: 10.1002/art.37838

[16] Fox, B. D., Shimony, A., Langleben, D., Hirsch, A., Rudski, L., Schlesinger, R., et al. (2013) .High prevalence of occult left heart disease in scleroderma-pulmonary hypertension. Eur. Respir. J., 42(4), 1083-91. doi: 10.1183/09031936.00091212

[17] Avouac, J., Airò, P., Meune, C., Beretta, L., Dieude, P., Caramaschi, P. et al. (2010) Prevalence of pulmonary hypertension in systemic sclerosis in European Caucasians and metaanalysis of 5 studies. J. Rheumatol., 37(11), 2290-8. doi: 10.3899/jrheum.100245

[18] Tedford, R. J., Hassoun, P. M., Mathai, S. C., Girgis, R. E., Russell, S. D., Thiemann, D. R., et al. (2012) Pulmonary capillary wedge pressure augments right ventricular pulsatile loading. Circulation. 125(2) 289-97 doi: 10.1161/CIRCULATIONAHA.111.051540

[19] Dai, Z., \& Matsui, Y. (2014) Pulmonary veno-occlusive disease: an 80-year-old mystery. Respiration., 88(2), 148-57. doi: 10.1159/ 000359973

[20] Montani, D., Achouh, L., Dorfmüller, P., Le Pavec, J., Sztrymf, B. Tchérakian, C., et al. (2008) Pulmonary veno-occlusive disease: clinical, functional, radiologic, and hemodynamic characteristics and outcome of 24 cases confirmed by histology. Medicine (Baltimore), 87(4), 220-33. doi: 10.1097/MD.0b013e31818193bb

[21] Eyries, M., Montani, D., Girerd, B., Perret, C., Leroy, A., Lonjou, C., et al. (2014) EIF2AK4 mutations cause pulmonary veno-occlusive disease, a recessive form of pulmonary hypertension. Nat Genet., 46(1), 65-9. doi: $10.1038 /$ ng. 2844

[22] Lammi, M. R. Saketkoo, L. A., Gordon, J. K. \& Steen, V. D. (2018) Changes in hemodynamic classification over time are common in systemic sclerosis-associated pulmonary hypertension: insights from the PHAROS cohort. Pulmonary Circulation., 8(2), 2045893218757404. doi: $10.1177 / 2045893218757404$ 
[23] Frost, A. E., Farber, H. W., Barst, R. J., Miller, D. P., Elliott, C. G., \& McGoon, M. D. (2013) Demographics and outcomes of patients diagnosed with pulmonary hypertension with pulmonary capillary wedge pressures 16 to $18 \mathrm{~mm} \mathrm{Hg}$ : insights from the REVEAL Registry. Chest., 143(1), 185-195. doi: 10.1378/chest.11-1387

[24] Ciurzynski, M. B. P., Bienias, P., Lichodziejewska, B., Szewczyk, A., Glińska-Wielochowska, M., Jankowski, K., et al. (2008) Assessment of left and right ventricular diastolic function in patients with systemic sclerosis. Kardiol. Pol., 66, 269-276.

[25] Lazar, J. M., Flores, A. R., Grandis, D. J., Orie, J. E., \& Schulman, D. S. (1993) Effects of chronic right ventricular pressure overload on left ventricular diastolic function. Am J Cardiol., 72(15), 1179-82. https:// doi.org/10.1016/0002-9149(93)90990-T

[26] Rubenfire, M., Huffman, M. D., Krishnan, S., Seibold, J. R., Schiopu, E., \& McLaughlin, V. V. (2013) Survival in systemic sclerosis with pulmonary arterial hypertension has not improved in the modern era. Chest., 144(4), 1282-1290. doi: 10.1378/chest.12-0653

[27] DETECT - DETECTion of PAH in SSC. Retrieve from http://detect-pah. com.

[28] Thibodeau, J. T., Turer, A. T., Gualano, S. K., Ayers, C. R., Velez-Martinez, M., Mishkin, J. D., et al. (2014) Characterization of a novel symptom of advanced heart failure: bendopnea. JACC Heart Fail., 2(1), 24-31. doi: 10.1016/j.jchf.2013.07.009

[29] Brandon, N., \& Mehra, M. R. (2013) «Flexo-dyspnea»: A novel clinical observation in the heart failure syndrome. J Heart Lung Transplant., 32(8), 844-5. doi: 10.1016/j.healun.2013.06.006

[30] van den Hoogen, F., Khanna, D., Fransen, J., Johnson, S. R., Baron, M., Tyndall, A., et al. (2013) 2013 classification criteria for systemic sclerosis: an American College of Rheumatology/European league against rheumatism collaborative initiative. Ann Rheum Dis., 72(11), 1747-55. doi: 10.1136/annrheumdis-2013-204424 